\title{
Parasitological assessment in the hybrid surubim (Pseudoplatystoma reticulatum $x$ P. corruscans), with uncommon occurrence of Monogenea parasites
}

\author{
Avaliação parasitológica no híbrido surubim (Pseudoplatystoma reticulatum x P. corruscans), \\ com ocorrência incomum de parasitos Monogenea
}

Gabriela Tomas Jerônimo ${ }^{1,2 *}$; Santiago Benites de Pádua ${ }^{3}$; Arlene Sobrinho Ventura ${ }^{4}$;

Eduardo Luis Tavares Gonçalves²; Márcia Mayumi Ishikawa'; Maurício Laterça Martins²

\author{
${ }^{1}$ Pós-graduação em Aquicultura, Universidade Nilton Lins/INPA, Manaus, AM, Brasil \\ ${ }^{2}$ AQUOS - Laboratório de Sanidade de Organismos Aquáticos, Departamento de Aquicultura, Universidade Federal de Santa \\ Catarina - UFSC, Florianópolis, SC, Brasil \\ ${ }^{3}$ Aquivet - Saúde Aquática, São José do Rio Preto, SP, Brasil \\ ${ }^{4}$ Programa de Pós-graduaçáo em Recursos Naturais, Universidade Estadual de Mato Grosso do Sul - UEMS, Dourados, MS, Brasil \\ ${ }^{5}$ Embrapa Meio Ambiente, Empresa Brasileira de Pesquisa Agropecuária - EMBRAPA, Jaguariúna, SP, Brasil
}

Received February 3, 2016

Accepted April 25, 2016

\begin{abstract}
This study evaluated the parasite fauna of farmed hybrid surubim (Pseudoplatystoma reticulatum $\mathrm{x} P$. corruscans) and the host-parasite-environment relationship in two fish farms located in Mato Grosso do Sul, Central Brazil, South America. A total of 120 hybrids from two different farms, 60 in each season (30 in the hot and 30 in cold season) were examined during a year. Water quality was weekly measured to evaluate the interaction among environmental conditions and parasitism. Histopathology was used to observe the effects of the parasites and environment on the fish gills. The ciliate protozoan Ichthyophthirius multifliis and the monogeneans (Ameloblastella sp., Amphocleithrium paraguayensis, Vancleaveus ciccinus, V. fungulus and V. janacauensis) were the most prevalent parasites detected in both seasons in both farms, with prevalence above $80 \%$. It was stated that parasites did not cause important damage in the health status of the hybrid surubim. These results might be related to general good management practices and environmental quality implemented by the fish farmers. The presence of uncommon monogenean parasites to this hybrid compared to their parents causing an environmental and ecological concern is here discussed.
\end{abstract}

Keywords: Fish farming, catfish, helminthes, protozoans, water quality.

\section{Resumo}

Este estudo avaliou a fauna de parasitos do surubim híbrido cultivado (Psendoplatystoma reticulatum $\mathrm{x}$ P. corruscans) e a relação hospedeiro-parasito-ambiente em duas pisciculturas localizadas no Estado do Mato Grosso do Sul, região Centro-Oeste, Brasil. Um total de 120 híbridos de duas fazendas, 60 em cada estação (30 na estaçáo quente e 30 na fria), foram examinados durante um ano. A qualidade da água foi medida semanalmente para avaliar a interação entre as condiçóes ambientais e o parasitismo. Histopatologia foi usada para observar os efeitos dos parasitos e do ambiente nas brânquias dos peixes. O protozoário ciliado Ichthyophthirius multifiliis e Monogenea (Ameloblastella sp., Amphocleithrium paraguayensis, Vancleaveus ciccinus, V. fungulus e V. janacauensis) foram os parasitos mais prevalentes detectados em ambas estaçôes nas duas fazendas, com prevalências acima de $80 \%$. Observou-se que os parasitos náo causaram danos ao estado de saúde do surubim híbrido. Esses resultados estão relacionados às boas práticas de manejo e qualidade ambiental implementada pelos produtores. É discutida a presença incomum de Monogenea para esse híbrido, comparado com seus progenitores, podendo causar preocupação ambiental e ecológica.

Palavras-chave: Piscicultura, bagre, helmintos, protozoários, qualidade de água.

\footnotetext{
*Corresponding author: Gabriela Tomas Jerônimo. Pós-graduação em Aquicultura, Universidade Nilton Lins/INPA, Av. Nilton Lins, 3259,

CEP 69058-030, Manaus, AM, Brasil. e-mail: gabriela.jeronimo@inpa.gov.br
} 


\section{Introduction}

The production of native catfish is an expanding activity in Brazil, where production is concentrated in the central region of the country. Due to the spread of hybridization in aquaculture, one of the most common farmed fish are the carnivores belonging to the genus Pseudoplatystoma (CARVALHO-COSTA et al., 2011).

The genus Pseudoplatystoma comprises eight species (BUITRAGO-SUÁREZ \& BURR, 2007), which includes the spotted surubim (Pseudoplatystoma corruscans Spix \& Agassiz, 1829) and the "cachara" (Pseudoplatystoma reticulatum Eigenmann \& Eigenmann, 1889). They are migratory fish, with great ecological importance and high commercial value in South America (BIGNOTTO et al., 2009). In nature, $P$. corruscans and $P$. reticulatum coexist in the Paraná watershed and their genetic proximity infers the ability to generate artificial hybrid catfish (BIGNOTTO et al., 2009). Currently, hybrid surubim catfish (Pseudoplatystoma sp.) stands in intensive production due to the great potential for industrial exploitation, rapid growth, efficient feed conversion, organoleptic quality and standard export (CREPALDI et al., 2006).

However, few studies have been carried out on parasitological assessment in hybrid surubim in Brazil. Naldoni et al. (2009) described the myxozoan Henneguya pseudoplatystoma from the gills of the hybrid surubim farmed in the of Mato Grosso do Sul. Jerônimo et al. (2013) evaluated the distribution of ectoparasites in the gill arches of this host under farming conditions. In the early stages of farming, Pádua et al. (2012) reported Ichthyophthirius multifiliis, Epistylis sp., Trichodina sp., Henneguya sp. and Monogenea as the main parasites affecting larval fish. Even in fish hatcheries, Pádua et al. (2013) showed higher parasitism by Epistylis sp., characterizing an emerging disease in Brazil. On the other hand, Ventura et al. (2013) have related Epistylis sp., Trichodina sp. and digenean metacercariae in post-larvae and fingerlings of the hybrid surubim.

In order to consolidate the production of this fish more studies are needed to understand the host/parasite/environment relationship to improve the knowledge of diseases responsible for economic losses (MARTINS et al., 2015). This study aimed to contribute to the knowledge of the parasite fauna in the hybrid catfish (P. reticulatum female $x$ P. corruscans male) and to establish the host/parasite/environment relationship during the cycle of two production systems.

\section{Materials and Methods}

\section{Sampling, fish farms and water quality}

One hundred and twenty hybrid surubim were collected between June 2010 and May 2011, 60 fish in each fish farm during warm and cold seasons, 30 fish per season. Both fish farms are located in Grande Dourados region (Farm A $22^{\circ} 19^{\prime} 42,7^{\prime \prime} \mathrm{S}$; $54^{\circ} 43^{\prime} 55,2^{\prime \prime} \mathrm{W}$ and Farm B $21^{\circ} 52^{\prime} 48,1^{\prime \prime}$ S; $54^{\circ} 20^{\prime} 39,2^{\prime \prime} \mathrm{W}$ ), Mato Grosso do Sul, Brazil. Fish farms are designed as A and B and their characterization is reported in Table 1.

Water quality was weekly measured: dissolved oxygen, temperature, $\mathrm{pH}$ and electrical conductivity were measured with multiparameter HANNA ${ }^{\circledR}$ (Hanna instruments, Inc, USA), transparency with the Secchi disk and alkalinity by titration method. Samples of farm output water were collected for orthophosphate, total ammonia, nitrite and nitrate determination by colorimetric kit (Alfakit ${ }^{\circledR}$, Brazil).

\section{Fish capture and parasitological survey}

The fish were caught by trawl, transferred to shipping boxes with aeration and transported to the Aquaculture Laboratory of Embrapa Western Region Agriculture to posterior euthanasia by deep in clove oil, $75 \mathrm{mg} \mathrm{L}^{-1}$ (Ethic Committee 29979/2009-05/ CEUA/UFSC 23080.0). Biometry and necropsy for parasitological analysis was according to Jerônimo et al. (2011). Helminthes

Table 1. Characteristics of fish farms used in this study.

\begin{tabular}{ccc}
\hline & Fish farm A & Fish farm B \\
\hline Size & 20 ha & 170 ha \\
Total water area & 5 ha & 130 ha \\
Size of pond & 0.48 ha & 1.2 ha \\
Fish farm purpose & Sportive fee fishing & Intensive production \\
Water supply & Water captured from Engano Stream & Individual entrance, water captured in São Domingos River \\
Fish origin & Commercial hatcheries & Own hatcheries \\
Density & 1 fish.m ${ }^{-2}$ & 4 fish.m ${ }^{-2}$ \\
Feeding & Once daily & Twice daily \\
Feed/Offer & $36 \%$ CP, $1.5 \%$ body weight & CP, $1.5-2 \%$ body weight \\
Aeration & Without aeration & If necessary \\
Water renewal & Yes & Yes, basically by replacing \\
Drying of ponds & No & Yes \\
Fish stage production & Juvenile/Adult & Juvenile \\
Consumer market & Fee fishing & Domestic market and export
\end{tabular}


infection levels were determined under a stereomicroscope, and the protozoans in a Sedwick Rafter chamber.

Parasites identification followed the methodology proposed by Eiras et al. (2006) and Thatcher (2006) and the parasitological descriptors were determined according to Bush et al. (1997).

\section{Histological analysis}

Gill fragments were collected and fixed in 10\% phosphate-buffered formalin, dehydrated in ascending series of alcohol, embedded in historesin (hydroxyethyl metacrylate - Leica historesin embedding kit - Leica Instruments, Germany), sectioned at $2 \mu \mathrm{m}$ thickness, stained with toluidine blue and observed under light microscopy.

\section{Statistical analysis}

Statistical analysis were performed using the Software IBM $^{\circledR}{ }^{\circledR}$ SPSS $^{\circledR}$ Statistics. Comparison of prevalence between the fish farms and between the seasons, was made by Chi-square test. The nonparametric Mann-Whitney $U$ test was also used to evaluate the biometric data and the intensity of infestation. The level of significance was set at $\mathrm{p}<0.05$. For water quality a Principal Component Analysis (PCA) of each fish farming was plotted.

\section{Results}

The mean weight, length and range of surubim collected from two fish farms in two sampling periods are reported in Table 2. Fish from farm A were significantly higher $(p=0.001)$ than that observed in fish farm B. The biggest fish were found in fish farm A in cold season $(\mathrm{p}=0.01)$.

Analyzing the water quality of fish farm A by Principal Components Analysis (PCA) 62\% of variance was explained by the two main factors (Figure 1). The results showed a factor strongly related to season and other related to water quality, highlighting a higher correlation between cold season and high levels of transparency, orthophosphate and dissolved oxygen, whereas the hot season was strongly correlated with higher levels of nitrite, nitrate and temperature. On the other hand, for fish farm B (Figure 2) PCA these factors accounted for $68 \%$ of variance, with a relationship between cold season and electrical conductivity.

In this study, were identified the ciliate protozoan I. multifiliis Fouquet, 1876, Trichodina sp. and Epistylis sp., the myxosporeans
Henneguya pseudoplatystoma Naldoni, Arana, Maia, Ceccarelli, Tavares, Borges, Pozo \& Adriano, 2009 and Myxobolus sp., the monogeneans Ameloblastella sp. Kritsky, Mendoza-Franco \& Scholz, 2000; A. paraguayensis Price \& Romero, 1969; Vancleaveus ciccinus Kritsky, Thatcher \& Boeger, 1986; V. fungulus Kritsky, Thatcher \& Boeger, 1986; and V.janacauensis Kritsky, Mendoza-Franco \& Scholz, 2000. The cestodes were identified as Choanoscolex abscissus Riggenbach, 1896 and Nomimoscolex sudobin Woodland, 1935 and Spatulifer rugosa Woodland, 1935. The crustaceans Lernaea cyprinacea Linnaeus, 1758 and Dolops carvalhoi Lemos de Castro, 1949 were also identified in this study.

Ichthyophthirius multifiliis and monogeneans were the most prevalent parasites (Table 3) in both fish farms during the two seasons. Ichthyophthirius multifliis showed an increase in the mean intensity of infection ( $\mathrm{p}=0.008)$ in cold season in fish farm A. Monogeneans showed a greater mean intensity in hot season in both fish farms ( $\mathrm{p}=0.008, \mathrm{p}=0.001)$ (Table 4). The myxozoan $H$. pseudoplatystoma presented the highest prevalence $(\mathrm{p}=0.001)$ in fish farm A in hot season. In contrast, Myxobolus sp. did not show significant difference between the seasons and fish farms.

Among the crustacean parasites, copepodids of L. cyprinacea showed increased prevalence $(\mathrm{p}=0.001)$ in fish farm B in cold season, as well as D. carvalhoi $(\mathrm{p}=0.004)$. Prevalence of cestodes was higher $(p=0.006)$ in fish farm $B$, but did not show seasonal variation. These worms also presented the highest mean intensity of infections ( $p=0.002)$ in cold season in fish farm B (Table 4).

Histological analysis revealed that all gills presented hyperplasia at the base of the secondary lamellae (Figure 3a), which may be attributed to the ammonia levels detected in both fish farms in both seasons. Monogenean parasites also caused hyperplasia and fusion of secondary lamellae (Figure 3b).

\section{Discussion}

This study reports an important a survey of parasite species affecting farmed hybrid surubim in South America. Dactylogyrids are monogeneans presenting high host specificity (LAMBERT \& EL GHARBI, 1995; WHITTINGTON et al., 2000). The dactylogyrids $A$. paraguayensis and $V$. fungulus were originally described infecting native $P$. corruscans (SURIANO \& INCORVAIA, 1995; TAKEMOTO et al., 2009), and this is the first report of these parasites in the hybrid surubim. However, $V$. ciccinus is originally found in Phractocephalus hemioliopterus (Pimelodidae), while $V$. janacauensis can be found parasitizing

Table 2. Means, standard deviation and range of hybrid surubim weight and length collected in cold and hot season in fish farms A and B, and significance of differences $(\mathrm{p}<0.05)$ in host size between seasons and farms.

\begin{tabular}{|c|c|c|c|c|c|c|c|c|c|}
\hline \multirow[b]{2}{*}{ Parameters } & \multicolumn{2}{|c|}{ Fish farm $\mathrm{A}$} & \multirow[b]{2}{*}{$p$} & \multicolumn{2}{|c|}{ Fish farm B } & \multirow[b]{2}{*}{$p$} & \multicolumn{2}{|c|}{ Total } & \multirow[b]{2}{*}{$p$} \\
\hline & $\begin{array}{l}\text { Cold season } \\
\quad(\mathbf{n}=30)\end{array}$ & $\begin{array}{l}\text { Hot season } \\
\quad(\mathbf{n}=30)\end{array}$ & & $\begin{array}{l}\text { Cold season } \\
\quad(\mathrm{n}=30)\end{array}$ & $\begin{array}{l}\text { Hot season } \\
\quad(\mathbf{n}=30)\end{array}$ & & $\begin{array}{l}\text { Fish farm A } \\
\quad(n=60)\end{array}$ & $\begin{array}{l}\text { Fish farm B } \\
\quad(\mathbf{n}=60)\end{array}$ & \\
\hline Weight $(\mathrm{g})$ & $\begin{array}{c}1,222 \pm 426 \\
(252-2250)\end{array}$ & $\begin{array}{c}747 \pm 248 \\
(300-1,170)\end{array}$ & 0.01 & $\begin{array}{r}613 \pm 121 \\
(338-910)\end{array}$ & $\begin{array}{r}554 \pm 152 \\
(328-816)\end{array}$ & NS & $\begin{array}{c}984 \pm 421 \\
(252-2,250)\end{array}$ & $\begin{array}{r}584 \pm 140 \\
(328-910)\end{array}$ & 0.001 \\
\hline Length $(\mathrm{cm})$ & $\begin{array}{l}50.5 \pm 5.0 \\
(36-62)\end{array}$ & $\begin{array}{c}46.4 \pm 4.3 \\
(36-57)\end{array}$ & 0.001 & $\begin{array}{c}42.3 \pm 3.0 \\
(36-50)\end{array}$ & $\begin{array}{c}42.0 \pm 3.0 \\
(36-47)\end{array}$ & NS & $\begin{array}{c}48.5 \pm 5.0 \\
(36-62)\end{array}$ & $\begin{array}{c}42.2 \pm 3.0 \\
(36-50)\end{array}$ & 0.001 \\
\hline
\end{tabular}


Grouping=Pintado PSA

Projection of the variables on the factor-plane $(1 \times 2)$

Active and Supplementary variables

${ }^{*}$ Supplementary variable

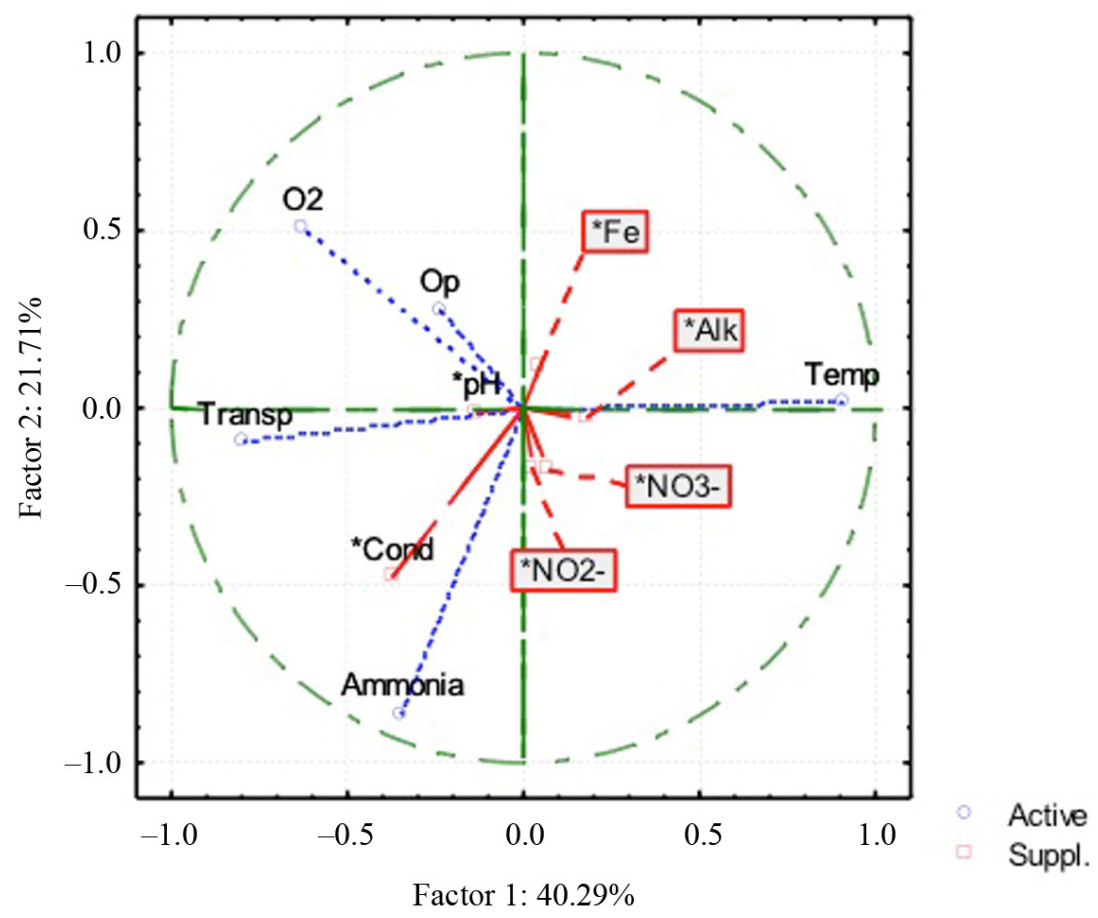

Grouping $=$ Pintado PSA

Projection of the cases on the factor-plane $(1 \times 2)$

Cases with sum of cosine square $>=0.00$

Labelling variable: Estação categoria

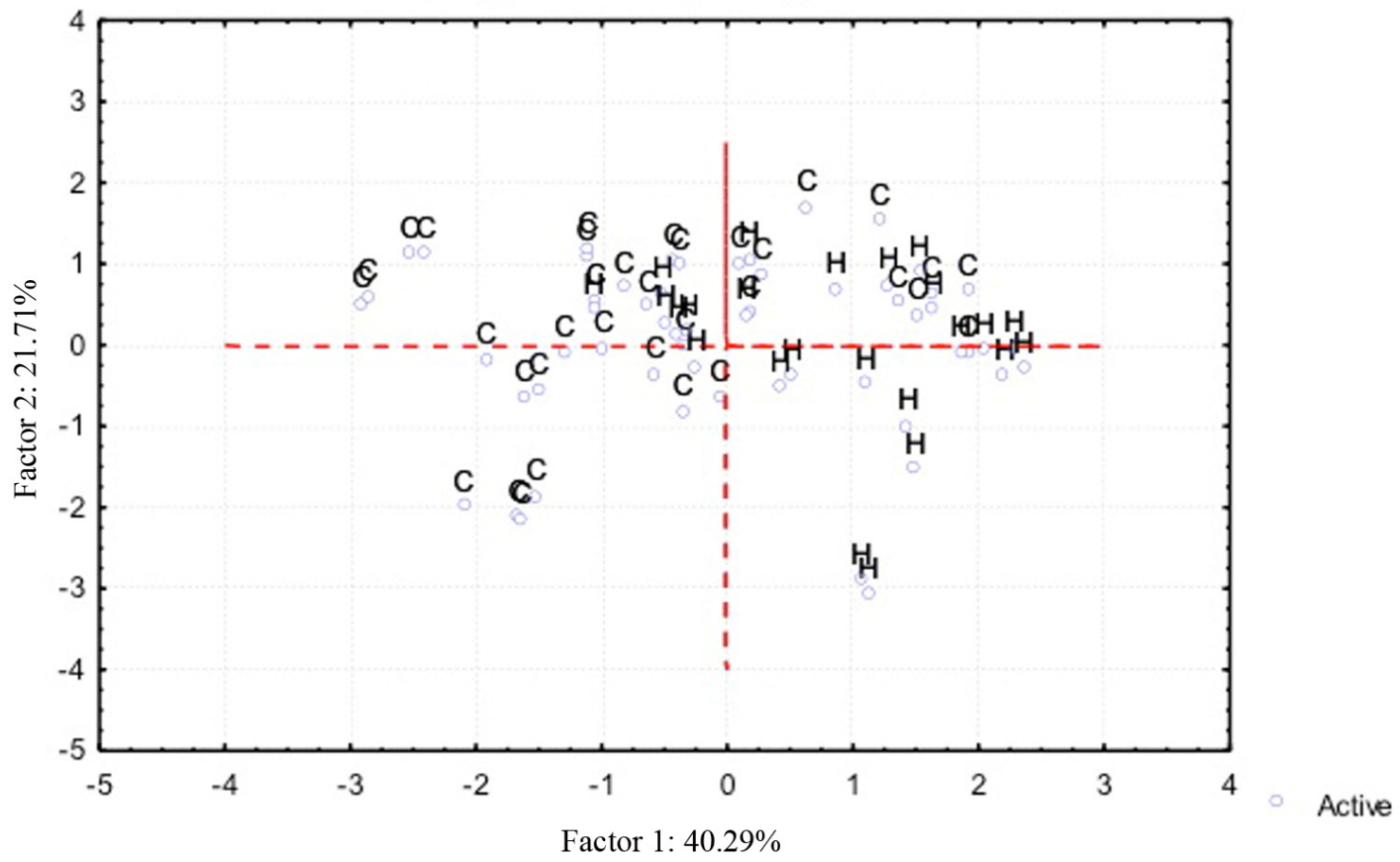

Figure 1. Principal components analysis (PCA) of water quality parameters from fish farm A (sportive fee fishing) of hybrid surubim. $\mathrm{O}_{2}$ : dissolved oxygen; Op: orthophosphate; Transp: transparency; Cond: electrical conductivity; Temp: temperature; Alk: alkalinity; Fe: iron; $\mathrm{C}$ : cold season; $\mathrm{H}$ : hot season. 
Grouping=Pintado MT

Projection of the variables on the factor-plane $(1 \times 2)$

Active and Supplementary variables

*Supplementary variable

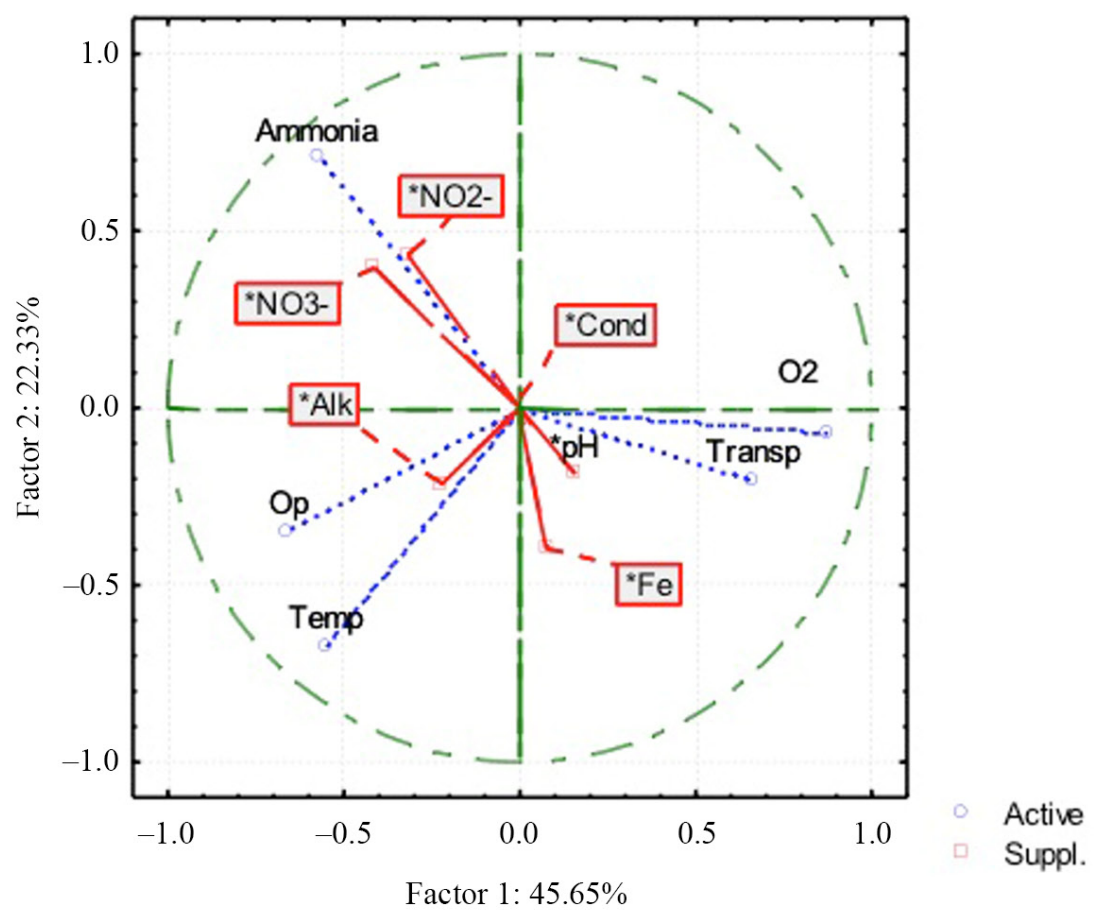

Grouping $=$ Pintado $\mathrm{MT}$

Projection of the cases on the factor-plane $(1 \times 2)$

Cases with sum of cosine square $>=0.00$

Labelling variable: Estação categoria

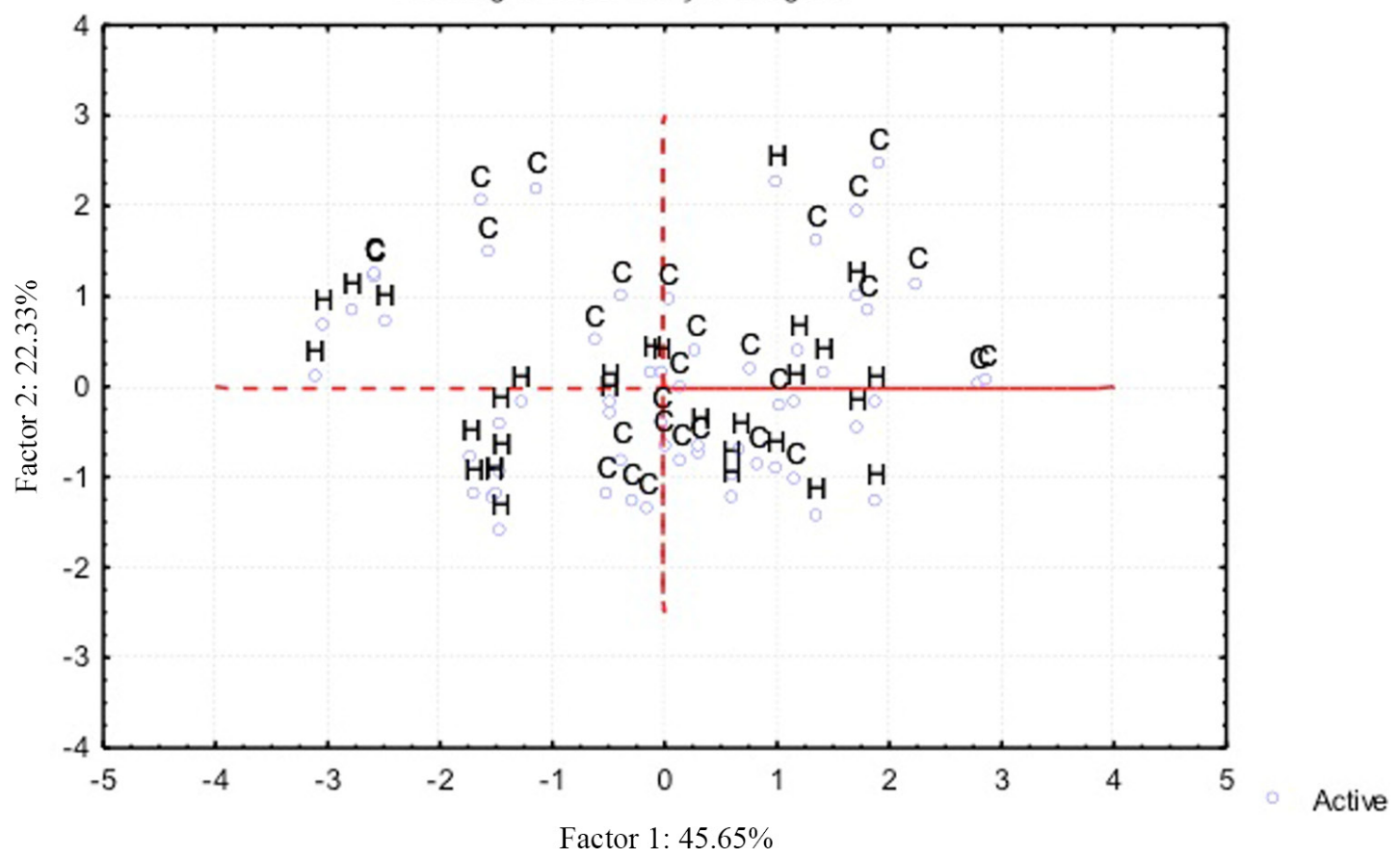

Figure 2. Principal components analysis (PCA) of water quality parameters from fish farm B (intensive production) of hybrid surubim. $\mathrm{O}_{2}$ : dissolved oxygen; Op: orthophosphate; Transp: transparency; Cond: electrical conductivity; Temp: temperature; Alk: alkalinity; Fe: iron; C: cold season; $\mathrm{H}$ : hot season. 

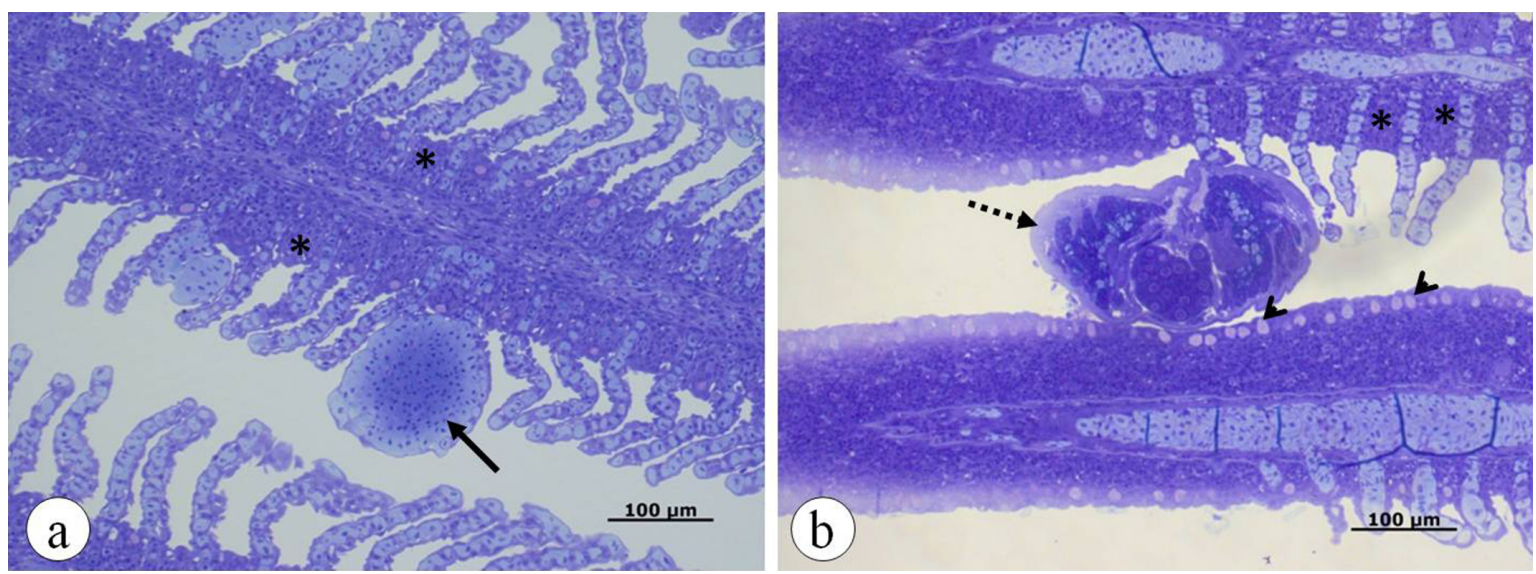

Figure 3. Histological sections of the gills of hybrid surubim. Telangiectasia (a - arrow) hyperplasia at the base of the secondary lamellae ( $\mathrm{a}, \mathrm{b}$ - asterisk), presence of monogenean between the gill filaments ( $\mathrm{b}$ - dotted arrow) with hyperplasia and fusion of secondary lamellae, and hyperplasia of mucosal cells adjacent to the parasite (b fabric - arrowheads). Staining: Toluidine Blue.

Table 3. Prevalence (\%) of hybrid surubim parasites. In cold and warm season in fish farm A and B and significant differences ( $\mathrm{p}<0.05)$ detected.

\begin{tabular}{|c|c|c|c|c|c|c|c|c|c|c|}
\hline \multirow[b]{2}{*}{ Parasites } & \multicolumn{2}{|c|}{ Fish farm A } & \multirow[b]{2}{*}{$p$} & \multicolumn{2}{|c|}{ Fish farm B } & \multirow[b]{2}{*}{$p$} & \multicolumn{2}{|c|}{ Total } & \multirow[b]{2}{*}{$p$} & \multirow[b]{2}{*}{$\begin{array}{l}\text { Site of infec- } \\
\text { tion }\end{array}$} \\
\hline & $\begin{array}{c}\text { Cold } \\
\text { Season } \\
(\mathrm{n}=30) \\
\end{array}$ & $\begin{array}{c}\text { Warm } \\
\text { Season } \\
(\mathrm{n}=30)\end{array}$ & & $\begin{array}{c}\text { Cold } \\
\text { Season } \\
(n=30) \\
\end{array}$ & $\begin{array}{c}\text { Warm } \\
\text { Season } \\
(\mathrm{n}=30)\end{array}$ & & $\begin{array}{c}\text { Fish farm } \\
\text { A } \\
(\mathrm{n}=60) \\
\end{array}$ & $\begin{array}{l}\text { Fish farm B } \\
\quad(n=60)\end{array}$ & & \\
\hline \multicolumn{11}{|l|}{ CILIOPHORA } \\
\hline I. multifiliis & 100 & 96.7 & NS & 100 & 93.3 & NS & 98.3 & 96.7 & NS & Gills and skin \\
\hline Trichodina sp. & 0 & 40 & 0.001 & 0 & 6.7 & NS & 20 & 3.3 & 0.010 & Gills \\
\hline Epistylis sp. & * & $*$ & $*$ & 50 & 30 & NS & 0 & 40 & 0.001 & Skin \\
\hline \multicolumn{11}{|l|}{ MYXOSPOREA } \\
\hline Henneguya sp. & 20 & 80 & 0.001 & 73.3 & 53.3 & NS & 50 & 60 & NS & $\begin{array}{l}\text { Gills, Liver } \\
\text { and Kidney }\end{array}$ \\
\hline Myxobolus sp. & 40 & 20 & NS & 23.3 & 16.7 & NS & 30 & 20 & NS & $\begin{array}{c}\text { Liver and } \\
\text { Kidney }\end{array}$ \\
\hline MONOGENEA & 100 & 83.3 & NS & 100 & 100 & NS & 91.7 & 100 & NS & Gills \\
\hline CESTODA & 0 & 26.7 & NS & 50 & 23.3 & NS & 13.3 & 36.7 & 0.006 & Intestine \\
\hline ACANTOCEPHALA & 0 & 3.3 & NS & 0 & 0 & NS & 1.7 & 0 & NS & Intestine \\
\hline \multicolumn{11}{|l|}{ CRUSTACEA } \\
\hline L. cyprinacea & 3.3 & 3.3 & NS & 53.3 & 3.3 & 0.001 & 3.3 & 28.3 & 0.001 & Gills \\
\hline D. carvalhoi & 36.7 & 3.3 & 0.004 & 10 & 0 & NS & 20 & 5 & 0.027 & Skin \\
\hline
\end{tabular}

*No observed. (NS) No significant; $(p<0.05)$ indicate significant difference between seasons for each parasite in each facility.

Table 4. Mean intensity (average \pm standard deviation, minimum and maximum values in parenthesis) of parasitism in hybrid surubim from different fish farms in Central Brazil.

\begin{tabular}{|c|c|c|c|c|c|c|c|c|c|}
\hline \multirow[b]{2}{*}{ Parasites } & \multicolumn{2}{|c|}{ Fish farm A } & \multirow[b]{2}{*}{$p$} & \multicolumn{2}{|c|}{ Fish farm B } & \multirow[b]{2}{*}{$p$} & \multicolumn{2}{|c|}{ Total } & \multirow[b]{2}{*}{$p$} \\
\hline & $\begin{array}{l}\text { Cold season } \\
\quad(\mathbf{n}=30)\end{array}$ & $\begin{array}{l}\text { Warm season } \\
\quad(\mathbf{n}=\mathbf{3 0})\end{array}$ & & $\begin{array}{c}\text { Cold season } \\
(\mathrm{n}=30)\end{array}$ & $\begin{array}{c}\text { Warm season } \\
(\mathbf{n}=30)\end{array}$ & & $\begin{array}{c}\text { Fish farm A } \\
(\mathrm{n}=60)\end{array}$ & $\begin{array}{c}\text { Fish farm B } \\
(\mathrm{n}=60)\end{array}$ & \\
\hline \multicolumn{10}{|l|}{ PROTOZOA } \\
\hline I. multifiliis & $\begin{array}{c}13,351 \pm 13,971 \\
(147-56,140)\end{array}$ & $\begin{array}{c}1,919 \pm 1,402 \\
(157-5,890)\end{array}$ & 0.004 & $\begin{array}{l}3,258 \pm 2,909 \\
(480-13,800)\end{array}$ & $\begin{array}{l}3,265 \pm 2,600 \\
(143-11,267)\end{array}$ & NS & $\begin{array}{c}7,732 \pm 11,479 \\
(147-56,140)\end{array}$ & $\begin{array}{l}3,261 \pm 2,737 \\
(143-13,800)\end{array}$ & 0.002 \\
\hline Trichodina sp. & $*$ & $\begin{array}{c}344.9 \pm 221.4 \\
(107-960)\end{array}$ & NS & ( & $\begin{array}{c}155 \pm 0.0 \\
(155-155)\end{array}$ & NS & $\begin{array}{c}344.9 \pm 221.4 \\
(107-960)\end{array}$ & $\begin{array}{c}155 \pm 0,0 \\
(155-155)\end{array}$ & NS \\
\hline MONOGENEA & $\begin{array}{c}88 \pm 84.4 \\
(7-378)\end{array}$ & $\begin{array}{c}44.3 \pm 48.5 \\
(2-160)\end{array}$ & 0.008 & $\begin{array}{c}117.4 \pm 78.2 \\
(17-383)\end{array}$ & $\begin{array}{c}252.1 \pm 1.88 \\
(65-934)\end{array}$ & 0.001 & $\begin{array}{c}68.6 \pm 73.5 \\
(2-378)\end{array}$ & $\begin{array}{c}184,8 \pm 158,0 \\
(17-934)\end{array}$ & 0.001 \\
\hline \multicolumn{10}{|l|}{ CRUSTACEA } \\
\hline L. cyprinacea & $\begin{array}{c}3 \pm 0 \\
(3-3)\end{array}$ & $\begin{array}{c}1 \pm 0 \\
(1-1)\end{array}$ & NS & $\begin{array}{c}5.5 \pm 3.7 \\
(1-12)\end{array}$ & $\begin{array}{c}2 \pm 0 \\
(2-2)\end{array}$ & NS & $\begin{array}{c}2.0 \pm 1.4 \\
(1-3)\end{array}$ & $\begin{array}{c}5.3 \pm 3.7 \\
(1-12)\end{array}$ & NS \\
\hline CESTODA & * & $\begin{array}{c}3.4 \pm 3.5 \\
(1-10)\end{array}$ & NS & $\begin{array}{c}14.2 \pm 9.4 \\
(3-31)\end{array}$ & $\begin{array}{c}3.0 \pm 2.5 \\
(1-7)\end{array}$ & 0.002 & $\begin{array}{c}3.4 \pm 3.5 \\
(1-10)\end{array}$ & $\begin{array}{c}10.6 \pm 9.5 \\
(1-31)\end{array}$ & 0.024 \\
\hline
\end{tabular}

${ }^{*}$ No observed. (NS) No significant; $(p<0.05)$ indicate significant difference between seasons for each parasite in each facility 
Pterodoras granulosus (Doradidae) (SURIANO \& INCORVAIA, 1995), both South American catfishes of the order Siluriformes. Dupont \& Crivelli (1988) observed that cyprinid hybrids may harbor parasites from both parental species and even some from non-related species.

The occurrence of $V$. ciccinus and $V$.janacauensis in the hybrid surubim was uncommon and may be related to interspecific hybridization, which makes them the target of ecological concern by its ability to harbor unusual parasites. Šimková et al. (2013) argued that the role of fish hybridization on parasite specificity is not yet clear, there may be changes in parasitic fauna due to host co-adaptation, though hybrids may harbor parasites from both parental species. We note that this may pose an important ecological issue, because with higher numbers of cultured fish, natural stocks may be greatly affected by parasites from cultured stocks, a situation seen before in salmonids (MCVICAR, 1997; TORRISSEN et al., 2013).

Although in this study the mean intensity of monogeneans varied from 44.3 to 252.1 parasites per host, the histopathological analyzes did not show severe tissue injury associated with the parasitism. Proliferative changes in the gill epithelium are among the main disorders observed during the infestation by monogenean (MANSELL et al., 2005; DEL RIO-ZARAGOZA et al., 2010; JERÔNIMO et al., 2014) and can progress to degeneration and necrosis of respiratory tissue, especially in mixed infections with other parasites (YARDIMCI \& PEKMEZCI, 2012). The severity of injuries caused by dactylogyrids are directly related to the parasite intensity (DEL RIO-ZARAGOZA et al., 2010). Sub-lethal lesions in fish were observed in varied degrees of infestations. However, higher infestation intensities result in more pronounced lesions (DEL RIO-ZARAGOZA et al., 2010). Nevertheless, in this study histopathological lesions were not limited to parasite infestation site, thus may also be due to poor water quality. These histopathological lesions are observed in fish submitted to culture conditions, including those exposed to high ammonia levels (PAUL \& BANERJEE, 1997).

The proliferation of $I$. multifliis is strongly related to periods of lower temperatures in tropical regions (MARTINS et al., 2015) coinciding with the highest water transparency, higher levels of dissolved oxygen and orthophosphate. Crustaceans were also observed in periods of low temperature. In contrast, in periods of higher temperature, an increase in the aquatic productivity occurs reflecting in nitrogen and conductivity alterations as observed on the monogenean parasitism in fish from farm B. In fact, an increase in the number of monogenean might be associated with environmental quality deterioration (MODU et al., 2012; ZARGAR et al., 2012) favoring its reproduction.

Although proteocephalid cestodes are commonly found parasitizing native Pseudoplatystoma spp. (SANTOS et al., 2003; CAMPOS et al., 2009), no reports were until now observed in the hybrid surubim. Its occurrence in farmed hybrid surubim was lower than that observed in cachara (P. reticulatum) from the natural environment (CAMPOS et al., 2008).

The undissociate ammonia molecule $\mathrm{NH}_{3}$, is highly toxic for fish and even low levels can cause gill hyperplasia (see ROBERTS, 2012) as observed in the present study. It is strongly advisable that fish farmers increase water renewal in order to improve fish health status of this economically important fish culture.

We also highlight that the role of fish hybridization in parasite specificity is a promising field of study and understanding about it, may contribute to the development of sanitary control measures and prevent possible ecological impacts.

\section{Acknowledgements}

The authors thank National Council for Scientific and Technological Development (CNPq) for financial support (CNPq 577657/2008-9) and research grant to M.L. Martins (CNPq 305869/2014-0); Ministry of Fisheries and Aquaculture; Brazilian Agricultural Research Corporation (EMBRAPA) - Project "AQUABRASIL" and Coordination for the Improvement of Higher Education Personnel (CAPES) for doctoral scholarship to G.T. Jerônimo (CAPES/BEX 9655-11-5). The manuscript was critically reviewed by Drs. E. Zaniboni-Filho (Aquaculture Department, UFSC), E.A. Adriano (Federal University of São Paulo, SP) and M. Tavares-Dias (EMBRAPA Amapá, AM) prior to submission.

\section{References}

Bignotto TS, Prioli AJ, Prioli SMAP, Maniglia TC, Boni TA, Lucio LC, et al. Genetic divergence between Pseudoplastystoma corruscans and Pseudoplatystoma reticulatum (Siluriformes: Pimelodidae) in the Paraná River Basin. Braz J Biol 2009;69(2 Suppl): 681-689. http://dx.doi. org/10.1590/S1519-69842009000300022. PMid:19738974.

Buitrago-Suárez UA, Burr BM. Taxonomy of the catfish genus Pseudoplatystoma Bleeker (Siluriformes: Pimelodidae) with recognition of eight species. Zootaxa 2007; 1512: 1-38.

Bush AO, Lafferty KD, Lotz JM, Shostak AW. Parasitology meets ecology on its own terms: Margolis et al. revisited. J Parasitol 1997; 83(4): 575583. http://dx.doi.org/10.2307/3284227. PMid:9267395.

Campos CM, Fonseca VE, Takemoto RM, Moraes FR. Ecology of the parasitic endohelminth community of Pseudoplatystoma fasciatum (Linnaeus, 1776) (Siluriformes: Pimelodidae) from the Aquidauana River, Pantanal, State of Mato Grosso do Sul, Brazil. Braz J Biol 2009; 69(1): 93-99. http://dx.doi.org/10.1590/S1519-69842009000100011. PMid:19347150.

Campos CM, Fonseca VE, Takemoto RM, Moraes FR. Fauna parasitária de cachara Pseudoplatystoma fasciatum (Siluriforme: Pimelodidae) do rio Aquidauana, Pantanal Sul Mato-grossense, Brasil. Acta Sci Biol Sci 2008; 30(1): 91-96. http://dx.doi.org/10.4025/actascibiolsci.v30i1.1469.

Carvalho-Costa LF, Piorski NM, Willis SC, Galetti JR Jr, Ortí G. Molecular systematics of the Neotropical shovelnose catfish genus Pseudoplatystoma Bleeker 1862 based on nuclear and mtDNA markers. Mol Phylogenet Evol 2011; 59(1): 177-194. http://dx.doi.org/10.1016/j. ympev.2011.02.005. PMid:21315164.

Crepaldi DV, Faria PMC, Teixeira EA, Ribeiro LP, Costa AAP, Melo DC, et al. O surubim na aquacultura do Brasil. Rev Bras Reprod Anim 2006; 30(3-4): 150-158.

Del Rio-Zaragoza OB, Fajer-Avila EJ, Almazán-Rueda P. Haematological and gill responses to an experimental infection of dactylogyrid monogeneans 
on the spotted rose snapper Lutjanus guttatus (Steindachner, 1869). Aquacult Res 2010; 41(11): 1592-1601. http://dx.doi.org/10.1111/j.13652109.2009.02471.x.

Dupont F, Crivelli AJ. Do parasites confer a disadvantage to hybrids? A case study of Alburnus alburnus $\mathrm{x}$ Rutilus rubilio, a natural hybrid of Lake Mikri Prespa, Northern Greece. Oecologia 1988; 75(4): 587-592. http://dx.doi.org/10.1007/BF00776424.

Eiras JC, Takemoto RM, Pavanelli GC. Métodos de estudo e técnicas laboratoriais em parasitologia de peixes. 2nd ed. Maringá: Eduem; 2006.

Jerônimo GT, Gonçalves ELT, Bampi D, Paseto A, Pádua SB, Ishikawa MM, et al. Microhabitat of monogenea and copepodids of Lernaea cyprinacea on the gills of four Brazilian freshwater fish. Neotrop Helminthol 2013; 7(1): 65-74.

Jerônimo GT, Martins ML, Ishikawa MM, Ventura AS, Tavares-Dias M. Métodos para coleta de parasitos de peixes. Circular Técnica Embrapa Macapá 2011; 39: 1-6.

Jerônimo GT, Pádua SB, Bampi D, Gonçalves ELT, Garcia P, Ishikawa $\mathrm{MM}$, et al. Haematological and histopathological analysis in South American fish Piaractus mesopotamicus parasitized by monogenean (Dactylogyridae). Braz J Biol 2014; 74(4): 1000-1006. http://dx.doi. org/10.1590/1519-6984.09513. PMid:25627614.

Lambert A, El Gharbi S. Monogenean host specificity as a biological and taxonomic indicator for fish. Biol Conserv 1995; 72(2): 227-235. http:// dx.doi.org/10.1016/0006-3207(94)00085-5.

Mansell B, Powell MD, Ernst I, Nowak BF. Effects of the gill monogenean Zeuxapta seriolae (Meserve, 1938) and treatment with hydrogen peroxide on pathophysiology of kingfish, Seriola lalandi Valenciennes, 1833. J Fish Dis 2005; 28(5): 253-262. http://dx.doi.org/10.1111/j.13652761.2005.00625.x. PMid:15892750.

Martins ML, Cardoso L, Marchiori NC, Pádua SB. Protozoan infections in farmed fish from Brazil: diagnosis and pathogenesis. Rev Bras Parasitol Vet 2015; 24(1): 1-20. http://dx.doi.org/10.1590/S1984-29612015013. PMid:25909248.

$\mathrm{McVicar} \mathrm{AH}$. Disease and parasite implications of the coexistence of wild and cultured Atlantic salmon populations. J Mar Sci 1997; 54: 1093-1103.

Modu BM, Saiful M, Kartini M, Kasim Z, Hassan M, Shaharom-Harrison FM. Effects of Water quality and monogenean parasite in the gills of freshwater catfish, Hemibagru snemurus Valenciennes 1840. Res J Biol Sci 2012; 4: 242-246.

Naldoni J, Arana S, Maia AAM, Ceccarelli PS, Tavares LER, Borges FA, et al. Henneguya pseudoplatystoma n. sp causing reduction in epithelial area of gills in the farmed pintado, a South American catfish: Histopathology and ultrastructure. Vet Parasitol 2009; 166(1-2): 52-59. http://dx.doi. org/10.1016/j.vetpar.2009.07.034. PMid:19695782.

Pádua SB, Ishikawa MM, Kasai RYD, Jerônimo GT, Carrijo-Mauad JR. Parasitic infestations in hybrid surubim catfish fry (Pseudoplatystoma reticulatum $\mathrm{x}$ P. corruscans). Braz J Vet Med 2012; 34(3): 235-240.
Pádua SB, Ishikawa MM, Ventura AS, Jerônimo GT, Martins ML, Tavares LER. Brazilian catfish parasitized by Epistylis sp. (Ciliophora, Epistylididae), with description of parasite intensity score. Parasitol Res 2013; 112(1): 443-446. http://dx.doi.org/10.1007/s00436-012-3069-5. PMid:22890898.

Paul VI, Banerjee TK. Histopathological changes induced by ambient ammonia (ammonium sulphate) on the opercular linings of the catfish Heteropneustes fossilis. Dis Aquat Organ 1997; 28: 151-161. http://dx.doi. org/10.3354/dao028151.

Roberts RJ. Fish pathology. 4th ed. London: WB. Saunders; 2012. 472 p. http://dx.doi.org/10.1002/9781118222942.

Santos SMC, Ceccarelli PS, Rêgo RF. Helminths in fish from Pantanal of the Mato Grosso do Sul: first expedition of the Pantanal Program. Bol Téc CEPTA 2003; 16: 15-26.

Šimková A, Dávidová M, Papoušek I, Vetešník L. Does interspecies hybridization affect the host specificity of parasites in cyprinid fish? Parasit Vectors 2013; 6(1): 95. http://dx.doi.org/10.1186/1756-33056-95. PMid:23587287.

Suriano DM, Incorvaia IS. Ancyrocephalid (Monogenea) parasites from siluriform fishes from the Paranean-Platean ichthyogeographical province in Argentina. Acta Parasitol 1995; 40(3): 113-124.

Takemoto RM, Pavanelli GC, Lizama MAP, Lacerda ACF, Yamada FH, Moreira LHA, et al. Diversity of parasites of fish from the Upper Paraná River floodplain, Brazil. Braz J Biol 2009;69(2 Suppl): 691-705. http:// dx.doi.org/10.1590/S1519-69842009000300023. PMid:19738975.

Thatcher VE. Amazon fish parasites. Sofia-Moscow: Pensoft; 2006.508 p.

Torrissen O, Jones S, Asche F, Guttormsen A, Skilbrei OT, Nilsen F, et al. Salmon lice: impact on wild salmonids and salmon aquaculture. J Fish Dis 2013; 36(3): 171-194. http://dx.doi.org/10.1111/jfd.12061. PMid:23311858.

Ventura AS, Jerônimo GT, Gonçalves ELT, Tamporoski BRF, Martins ML, Ishikawa MM. Parasitic fauna of the siluriform hybrids cachapinta and jundiara in the first stages of development. Pesq Agropec Bras 2013 48(8): 943-949. http://dx.doi.org/10.1590/S0100-204X2013000800019.

Whittington ID, Cribb BW, Hamwood TE, Halliday JA. Host-specificity of monogenean (Platyhelminth) parasites: a role for anterior adhesive areas? Int J Parasitol 2000; 30(3): 305-320. http://dx.doi.org/10.1016/ S0020-7519(00)00006-0. PMid:10719124.

Yardimci B, Pekmezci GZ. Gill histopathology in cultured sea bass (Dicentrarchus labrax (L.) co-infected by Diplectanum aequans (Wagener, 1857) and Lernanthropus kroyeri (van Beneden, 1851). Ankara Univ Vet Fak Derg 2012; 59(1): 61-64. http://dx.doi.org/10.1501/Vetfak_0000002502.

Zargar UR, Chishti MZ, Yousuf AR, Fayaz A. Infection level of monogenean gill parasite, Diplozoon kashmirensis (Monogenea, Polyopisthocotylea) in the Crucian carp, Carassius carassius from lake ecosystems of an altered water quality: What factors do have an impact to the Diplozoon infection? Vet Parasitol 2012; 189(2-4): 218-226. http://dx.doi.org/10.1016/j. vetpar.2012.04.029. PMid:22608705. 